\title{
A survey of the incidence of worm parasites in laying chickens in Abak Local Government Area, Akwa Ibom State, Nigeria
}

\author{
Princewill Emmanuel Johnson $^{1 \star}$, Edem E. A. Offiong ${ }^{1}$, Ekeminilni Henry ${ }^{2}$ \\ ${ }^{1}$ Animal Science Department, Akwa Ibom State University, Obio Akpa Campus, Nigeria. \\ ${ }^{2}$ Animal Science Department, University of Uyo, Uyo, Nigeria. \\ ${ }^{*}$ Correspondent author. Email: princewilljohnson0@gmail.com
}

Copyright @ 2019 Johnson et al. This article remains permanently open access under the terms of the Creative Commons Attribution License 4.0, which permits unrestricted use, distribution, and reproduction in any medium, provided the original work is properly cited.

Received 1st December, 2018; Accepted 2nd January, 2019

\begin{abstract}
This research is based on parasitic helminthes of laying birds conducted in July 2018 in the Department of Animal Science, Akwa Ibom State University, Akwa Ibom State, Nigeria. This work aimed at identifying the types of worm parasites that may be found in laying birds (poultry) farms and to determine their prevalent rates in layers together with the percentage infestation of these worm parasites in Abak Local Government Area. A total of 270 sterile samples were collected randomly from 10 farms in 3 weeks at Abak Local government Area. These sterile samples were transported immediately for analysis in the laboratory using floatation method with saturated salt solution. With the aid of $x 10$ microscope, it was discovered that out of the 270 (or 100\%) samples examined for helminthes only two types of nematodes were identified. A sum total of 196 (or 73\%) nematode eggs were found and a total of 113 (or $42 \%$ ) Ascardia gallinarum eggs were tested positive and 83 (or 31\%) Heterakis gallinarum were tested positive while a total of 74 (or $27 \%$ ) fecal sample tested negative. The high prevalence of gastrointestinal helminthes as observed in this area has a strong relationship with their mode of feeding and living conditions which lead to reduced body weight, decreased egg production and deaths thus affecting the meat quality and nutrient content of the chicken. Laying birds should be dewormed every three months and high level of hygiene should be maintained in the farm. It was concluded that there is a high prevalence of helminthes in Abak Local government Area in laying birds, which may lead to high losses. Thus, improved farm management and disease control to enhance their potentials is necessary.
\end{abstract}

Keywords: Birds, floatation, survey, worm parasites.

\section{INTRODUCTION}

Poultry birds are raised in great numbers with chickens being the most numerous. More than 50 billion chickens are raised annually as a source of food, for both their meat and their eggs. Poultry industry occupies an important position in the provision of animal protein (meat and egg) to man and generally plays a vital role in the national economy as a revenue provider. According to the researchers and scientists, $74 \%$ of the world's poultry meat and 68 percent of eggs are produced in ways that are described as intensive (world watch, 2006). Poultry is one of the most intensively reared of the domesticated species and one of the most developed and profitable animal enterprise (Obiora, 1992). In Nigeria, the population of poultry is estimated to be about 140 million with backyard poultry constituting about $60 \%$ thus, the most important form of poultry production (Ikpi and Akinwunmi, 1981).

Common poultry parasites range from lice, mites, fleas, ticks and helminthes to gnats and coccidia (Nnadi and George, 2010). Parasitism causes reduced growth, drop in egg production, emaciation and anaemia which results in high rate of mortality, etc. (Whitmarsh, 1997 and Ruff, 1999). In northern Nigeria, research study showed that the prevalence rate of helminth infection is about $70 \%$ (Yoriyo et al., 2008). Helminthosis was considered to be an 
important problem of local chicken and helminth parasites have been incriminated as a major cause of ill-health and loss of productivity in different parts of Nigeria (Fakae and Paul-Abiade, 2003). Poultry reared in rural scavenging system face various hindrances among which helminthiasis plays a vital role. Hence, studies conducted in different parts of the world indicated that the proportion of chicken infection with gastrointestinal helminthes is high, therefore helminthes are considered to be an important cause of ill health and reduction in poultry productivity (Ajala et al., 2007).

Nematodes, cestodes and trematodes are important parasites of poultry production. These parasites can be found in the intestine or faecal dropping especially when expelled as fresh specimen (Fakae and Paul-Abiade, 2003). Several species of cestodes (Tapeworm) may live in the intestinal tract of chicken. More than 1,400 tapeworms have been described in domesticated poultry and wild birds which are common in poultry free range or backyard flocks (Biu and Haddabi, 2005). These parasites are found more frequently in the warm seasons, when the intermediate hosts are abundant. Beetles and houseflies inhabiting poultry houses act as intermediate host for most species of cestodes (Baba and Oveka, 2004). In studies by Ruff (1999), $100 \%$ of the rural scavenging chicken examined in Cross River Nigeria, was positive for one or more helminthes parasites. In another study, Saidu et al (1994) reported 45\% of Ascaridia galli and 35\% Heterakis gallinarum.

Improved poultry management practices are responsible for the reduction in the incidence of parasitic infections (Puttalakshmamma et al., 2008). Prevalence studies have been undertaken in many tropical countries such as Nigeria (Nnadi and George, 2010), Kenya (Mungube et al., 2007), Zambia (Phiri et al., 2007). Thus, the objective of this study is to identify the types of worm parasites that may be found in laying birds (poultry) farms and to determine their prevalent rates in layers together with the percentage infestation of these worm parasites in Abak Local Government Area.

\section{MATERIALS AND METHODS}

\section{Study area}

The experiment was carried out within villages in Abak Local Government Area, Akwa Ibom State, Nigeria. Abak lies on the South West of Akwa lbom State and bounded in the North by Ikono Local Government Area, North West by Essien Udim Government Area, West by Etim Ekpo and Ukanafun Local Government Areas, South by Oruk Anam and in the East by Uyo Local Government Area. Abak town, the local government headquarters is located about 18 kilometres from Uyo, the State capital. It has a landmass of 304 square kilometers with a population of about 195,400. It has a global positioning system coordinates of $5^{\circ} 0^{\prime} 11.8296 " \mathrm{~N}$ and $7^{\circ} 46^{\prime} 27.372 " \mathrm{E}$. Abak is known for its importance in agricultural development. It has so many agro-based and agro allied industries located within it in which poultry production predominantly increased in population due to high demand for poultry birds and its products.

\section{Sample collection}

Three (3) fecal samples was obtained at random from ten (10) farms at each visit (Monday, Wednesday and Friday) for three weeks in sterile bottles and was immediately transported to Laboratory of the Department of Animal Science, Akwa Ibom State University, Akwa Ibom State, Nigeria for analysis using flotation method with saturated saline solution. A total of 270 samples were obtained in 3 weeks.

\section{Analysis of samples}

The samples were collected in sterile sample bottles (screw capped) and were immediately transported to the laboratory for investigation. Samples were analyzed immediately using simple saturated salt floatation method. The floatation solution was prepared by adding salt to a boiling water until the salt could no longer dissolve in the water. The solution was allowed to cool, decanted and stored in a sterile bottle for use when need arises. $3 \mathrm{~g}$ of each fecal sample was put into a beaker and the saturated salt solution poured into the beaker, while stirring to mix the fecal sample and the floatation solution well. The solution was poured into the test tube filled to the brim and then a cover slid was placed on top of the test tube with the content touching the slid. The mixture was allowed to stand in the rack for 30 minutes where the worm eggs were expected to float to the top. The coverlid was carefully removed and placed on a microscope for examination at $10 \times 10$ magnification power.

Identification of Nematodes species followed the criteria of Sloss et al. (1994) and the eggs for each species of parasite was counted and recorded. The rate of prevalence of each species of worm were calculated by dividing the number of fecal samples tested positive for worm eggs by the total number of fecal samples tested. The result was multiplied by 100 and expressed in percentage. Results were analyzed in simple percentage.

\section{RESULTS AND DISCUSSION}

Out of 270 (or $100 \%$ ) samples that were obtained and examined from 10 farms at 3 weeks, only nematode species were found. A total of $113(42 \%)$ Ascardia gallinarum eggs was tested positive and $83(31 \%)$ Heterakis gallinarum were tested positive while $74(27 \%)$ fecal sample of eggs tested negative as showed below in Table 1. At week one, a total of 28 Ascardia gallinarum and 
Table 1. Prevalence of parasitic worms in ten (10) farms at Abak Local Government Area, Akwa Ibom State, Nigeria, 2018.

\begin{tabular}{lcc}
\hline \multirow{2}{*}{ Name of farms } & \multicolumn{2}{c}{ Total no. of eggs } \\
\cline { 2 - 3 } & Ascaridia gallinarum & Heterakis gallinarum \\
\hline Farm A & 17 & 17 \\
Farm B & 19 & 3 \\
Farm C & 6 & 12 \\
Farm D & 10 & 2 \\
Farm E & 5 & 8 \\
Farm F & 15 & 3 \\
Farm G & 10 & 16 \\
Farm H & 5 & 11 \\
Farm I & 17 & 3 \\
Farm J & 9 & 8 \\
Grand total & 113 & 83 \\
Percentage of infection (\%) & 42 & 31 \\
\hline
\end{tabular}

Table 2. Weekly prevalence of parasitic worms in ten (10) farms at Abak Local Government Area, Akwa Ibom State, Nigeria, 2018.

\begin{tabular}{lccccc}
\hline Total no. of eggs & Week one & Week two & Week three & Grand total & Percentage of infection (\%) \\
\hline Ascaridia gallinarum & 28 & 46 & 39 & 113 & 42 \\
Heterakis gallinarum & 31 & 28 & 24 & 83 & 31 \\
\hline
\end{tabular}

31 Heterakis gallinarum eggs were found; at week two, a total of 46 Ascardia gallinarum and 28 Heterakis gallinarum eggs were found; and finally, at week three, a total of 39 Ascardia gallinarum and 24 Heterakis gallinarum eggs were found. The percentage Ascardia gallinarum infestation was $42 \%$ while the percentage Heterakis gallinarum infestation was $31 \%$ (Table 2). No record of cestodes and trematodes was found.

This study reveals that Nematode parasites were found in laying bird (layers) in Abak Local Government Area and they include; Ascaridia gallinarum and Heterakis gallinarum. Several studies on the incidence of helminth parasites have been conducted in some part of Nigeria and in other part of the world. As for this study, two helminth parasites were identified with Ascaridia gallinarum (42\%) ranking the highest in the list. This study is in agreement with the report by Ohaeri and Okwum (2013) which stated that nematodes especially Ascaridia gallinarum was the highest with prevalent percentage of $41.6 \%$ and studies by Alam et al. (2014) showed that Nematodes especially Ascaridia gallinarum had the highest prevalence with $41.56 \%$ which also agrees with this study. Similar reports of helminthes infection found in domestic fowl in this study have been documented as described from other parts of Nigeria (Offiong et al., 2013; Matur et al., 2010; Luka and Ndam, 2007). The prevalence of Heterakis gallinarum $(31 \%)$ recorded in this study is in agreement with Matur et al., 2010 who recorded $31 \%$ prevalence of Heterakis gallinarum in Abuja (FCT).
Rahman et al. (2009) observed that infection rates in nematodes depend on many factors namely, rainfall pattern, soil type, locality and the types of food given to the chickens which vary from place to place. The main effect of helminth parasite is the amazing losses they cause to animal industries through meat contamination and morbidity (Naem and Escaridari, 2005)

From the study, nematode had the highest prevalence with Ascaridia gallinarum having a remarkable prevalence of $42 \%$ and this is in agreement with earlier findings of Ohaeri and Okwum (2013) which means that nematodes are always more prevalent than cestodes and trematodes in domestic fowl. Reasons being that nematodes do not require intermediate hosts and at the same time they are soil transmitted parasites. The adults lay many eggs daily which can retain their viability for as long as 12 months and so domestic fowls are constantly picking up viable eggs from the droppings that contaminate the environment as they feed (Permin and Hansen, 1998) and this also predispose them for heavy parasite burden. More so, cestodes requires intermediate host to complete their life cycle and so transmission is dependent on the availability of the intermediate hosts.

\section{Conclusion and recommendation}

The investigation revealed that two types of worm parasites were found which include; Ascaridia gallinarum 
and Heterakis gallinarum. The prevalent rate of Ascardia gallinarum was $113(42 \%)$ while Heterakis gallinarum was $83(31 \%)$. A high prevalence of helminth infections in laying birds examined in the month of July with nematodes posing the greatest problem, Ascardia gallinarum was the most predominant nematodes followed by Heterakis gallinarum among laying birds in the area during the early rainy season.

Since this current study was conducted during the rainy season, there is need to carry out same study in the dry season with a view to comparing the rate of infection across seasons. Improvement of sanitary practices to interrupt the life cycle of the parasite species and as such reduce the rate as well as the burden of the infection in poultry farm is recommended. Maintenance of strict biosecurity measures in the farm and routine deworming to prevent increase rate of prevalence of worm parasites is essential. The public should be aware about occurrence and economic importance of worm parasites.

\section{CONFLICT OF INTEREST}

The authors declare that they have no conflict of interest.

\section{ACKNOWLEDGEMENT}

We sincerely appreciate our supervisor, Dr. Edem E. A. Offiong for his guidance and advice during this study.

\section{REFERENCES}

Ajala, M. K., Nwagu, B. I., \& Otchere, E.O. (2007). Socioeconomics of free range poultry production among Agropastoral women in Giwa Local Government Area of Kaduna State, Nigeria. Nigerian Veterinary Journal, 28(3), 1118.

Alam, M. N., Mostafa, M., Khan, M. A. H. N. A., Alim, M. A., Rahman, A. K. M. A., \& Trish,a A. A. (2014) Prevalence ofGastrointestinal Helminth Infections in Indigenous Chickens of Selected Areas of Barisal District, Bangladesh. Journal of Veterinary Medicine, 12(2), 135-139.

Baba, S. S., \& Oyeka, C. A. (2004). Prevalence of intestinal helminthes in poultry farms in Anambara State Nigeria. Bulletin of Animal Health Production in Africa, 37, 27-220.

Biu, A. A., \& Haddabi, I. (2005). An investigation of Tetrameres infection among local Chickens in Maiduguri. Nigerian Veterinary Journal, 26(1), 44-46.

Fakae, B. B., \& Paul-Abiade, C. U. (2003). Rainy season period prevalence of helminths in the domestic fowl (Gallus gallus) in Nsukka, Eastern Nigeria. Nigerian Veterinary Journal, 24(1), 21-27.

Ikpi, A, \& Akiniwumi J. 1981. The future of the poultry industry in Nigeria. World Poultry Sciences Journal, 37(1), 39-43.

Luka, S. A., \& Ndams, I. S. (2007). Gastrointestinal parasites of domestic chickens Gallus domesticus Linnaeus 1785 in Samaru Zaria, Nigeria. Science World Wide Journal, 2(1), 27.
Matur, B. M., Dawam, N. N., \& Malann Y. D. (2010). Gastrointestinal helminthes parasites of local and exotic chickens slaughtered in Gwagwalada, Abuja (FCT), Nigeria. New York Science Journal, 3(5), 96-99.

Mungube, E. O., Bauni, S. M., Tenhagen, B. A., Wamae, L. W., Nzioka, S. M., Muhammed, L., \& Nginyi, J. M. (2008). Prevalence of parasites of the local scavenging chickens in a selected semi-arid zone of Eastern Kenya. Tropical Animal Health and Production, 40(2), 101-109.

Naem, S., \& Eskandari, S. (2005). Prevalence of intestinal helminths of native chickens in Urmia, Iran. Iranian J. Vet. Res. Univ. Shiraz, 3(2), 200-203.

Nnadi, P. A., \& S. O. George (2010). A cross-sectional survey on parasites of chickens in selectedvillages in the sub humid zones of south-eastern Nigeria. Journal of Parasitology Research, Article ID 141824. doi:10.1155/2010/141824.

Obiora, F. C. (1992). A guide to poultry Production in the Tropics. 1st edition Acena Publishers. Pp. 59-382

Offiong, E. E. A., Obioku, O. E., Umoh, J. U., Essien, C. A., \& Idiong, N. B. (2013). A Survey of Gastrointestinal Helminthes of Local Chickens in Abak Local Government Area of Akwa Ibom State. International Journal of Science: Basic and Applied Research, 9(1), 1-4.

Ohaeri, C. C., \& Okwum, C. (2013). Helminthic parasites of domestic fowls in Ikwuano, Abia State Nigeria. Journal of Natural Sciences Research, 3(11), 5p.

Permin, A., \& Hansen, J. W. (1998). Diagnostic Methods: Epidemiology, Diagnosis and Control of Poultry Parasites. FAO animal health manual, No 4. Food and AgricultureOrganization of the United Nations, Rome, Italy; Pp. 33-118.

Phiri, I. K., Phiri, A. M., Ziela, M., Chota, A., Masuku, M., \& Monrad, J. (2007). Prevalence and distribution of gastrointestinal helminths and their effects on weight gain in free-range chickens in Central Zambia. Tropical Animal Health and Production, 39(4), 309-315.

Puttalakshmamma, G. C., Ananda, K. J., Prathiush, P. R., Mamatha, G. S., \& Rao, S. (2008). Prevalence of Gastrointestinal parasites of Poultry in and around Banglore. Veterinary World, 1(7), 201-202.

Rahman, A. W., Salim, H., \& Ghause, M. S. (2009). Helminthic parasites of scavenging chickens (Gallus domesticus) from villages in Penang Island, Malaysia. Tropical Life Science Resources, 20(1), 1-6.

Ruff, M. D. (1999). Important parasites in poultry production systems. Veterinary Parasitology, 84(3-4), 337-347.

Saidu, L., Abdu, P. A., Umoh, J. U., \& Abdullali, S. U. (1994). Diseases of indigenous Chicken. Bulletin of Anima I Health and Production in Africa, 42, 19-23.

Sloss, M. W., Kemp, R. L., \& Zajac, A. M. (1994). Veterinary clinical parasitology, 6th edition. lowa State University Press, lowa State of the World 2006 World Watch Institute, p. 26

Whitmarsh, S. (1997). Parasitic Diseases (Internal), Poultry science, Mississippi State University, Starkville, Miss, USA.

Yoriyo, K. P., Adang, K. L., Fabiyi J. P., \& Adamu, S. U. (2008). Helminth parsites of local chickens in Bauchi State Nigeria. Science World Journal, 3(2), 35-37. 